\title{
Composition and temporal dynamics of a temperate rocky cryptobenthic fish assemblage
}

\author{
R. Beldade*, K. Erzini ${ }^{\dagger}$ and E.J. Gonçalves** \\ *Eco-Ethology Research Unit, Instituto Superior de Psicologia Aplicada, R. Jardim do Tabaco 34, 1149-041 Lisboa, Portugal. \\ ${ }^{\dagger}$ CGMAR, Faculdade de Ciências do Mar e do Ambiente, Universidade do Algarve 8005-139 Faro, Portugal. \\ ${ }^{\ddagger}$ Corresponding author, e-mail: emanuel@ispa.pt
}

\begin{abstract}
Temporal variation in a temperate cryptobenthic fish assemblage at the Arrábida Marine Park (Portugal) was assessed by visual surveys during 2002 and 2003. A total of 9596 fish from 11 families and 30 species was recorded. There were no changes in structure or density at the assemblage level between years, whereas diversity changed significantly due to a higher number of abundant species in the second year. A similar seasonal trend was found between years, with a significant overall density increase in autumn. This is partially explained by the arrival of new recruits of some of the most abundant species in the assemblage. Assemblage diversity and structure also changed across seasons. A group of species encompassing Gobius xanthocephalus, Tripterygion delaisi, Parablennius pilicornis, Gobius paganellus, Lepadogaster candollii and Lepadogaster spp. were analysed in detail. The temporal patterns of two of the most abundant species, G. xanthocephalus and T. delaisi, mimicked the overall temporal patterns of the assemblage. We suggest that the inter-annual stability in density of this subtidal fish assemblage may be similar to what has been reported for the intertidal and that strong post-settlement processes are probably shaping this assemblage.
\end{abstract}

\section{INTRODUCTION}

Fish inhabiting the littoral rocky shores are not only valuable elements of coastal biodiversity, but they also exert an important ecological role in the functioning of littoral ecosystems (La Mesa et al., 2004). The ecological importance of cryptobenthic fish, as energy mediators (Depczynski \& Bellwood, 2003), justifies an increased effort aimed at a deeper understanding of this overlooked component of the rocky coast fish assemblages.

In the North Atlantic and Mediterranean several studies have been done on rocky coastal fish assemblages (Jansson et al., 1985; Minchin, 1987; Miniconi et al., 1990; Falcon et al., 1993; MacPherson, 1994; Reñones et al., 1997; La Mesa \& Vacchi, 1999; Gonçalves et al., 2002; Magill \& Sayer, 2002; La Mesa et al., 2004; Ordines et al., 2005). Most of these studies used traditional visual census methods to assess the whole fish assemblage, including cryptobenthic fish. These are 'small bodied fish $(<10 \mathrm{~cm})$ that exploit restricted habitats where food and shelter are obtained in, or in relation to, conditions of substrate complexity and/or restricted living space, with a physical barrier likely to be interposed between the small fish and sympatric predators' (cf. Miller, 1979).

Limitations to visual sampling of cryptobenthic fish have been recognized and tested by several authors (e.g. Harmelin-Vivien et al., 1985; Willis, 2001). Many community studies have either excluded these species (Anderson \& Millar, 2004; García-Charton et al., 2004) or sampled them using traditional visual census techniques (e.g. Ilich \& Kotrschall, 1990; La Mesa \& Vacchi, 1999; La Mesa et al., 2004). Disregarding or miss-sampling the small specimens in a community has, however, the potential to change any theoretical conclusions based on the observed patterns (Blackburn \& Gaston, 1996) due to the important role they can have on the overall community dynamics and functioning.

Studies on the temporal dynamics of coastal fish assemblages in temperate areas have shown strong seasonal and inter-annual variations in density for some species (Janson et al., 1985; Costello, 1992; Wilkins \& Myers, 1992; Magill \& Sayer, 2002). Temporal dynamics of fish populations have broadly been related to the input of recruits (e.g. Doherty \& Williams, 1988; Cushing, 1995) and to postsettlement mortality processes that may reshape initial settlement patterns (e.g. Forrester, 1995; Macpherson \& Zika, 1999). Observational studies at the assemblage level can assess inter-specific variation and also provide new insights into the variables affecting the temporal dynamics of coastal assemblages.

The objectives of this study were to: (1) describe the cryptobenthic fish assemblage occurring on the rocky shore of the Arrábida Marine Park; and (2) analyse the

Table 1. Time and number of census performed in each sampling period. Census correspond to strip transects laid perpendicularly to the coastline (see Materials and Methods).

\begin{tabular}{lccc}
\hline Year & Season & Time $(\min )$ & Census $(\mathbf{N})$ \\
\hline 2002 & Winter & 940 & 12 \\
& Spring & 897 & 10 \\
\multirow{2}{*}{2003} & Autumn & 919 & 16 \\
& Winter & 913 & 17 \\
& Spring & 887 & 17 \\
& Autumn & 888 & 15 \\
\hline
\end{tabular}



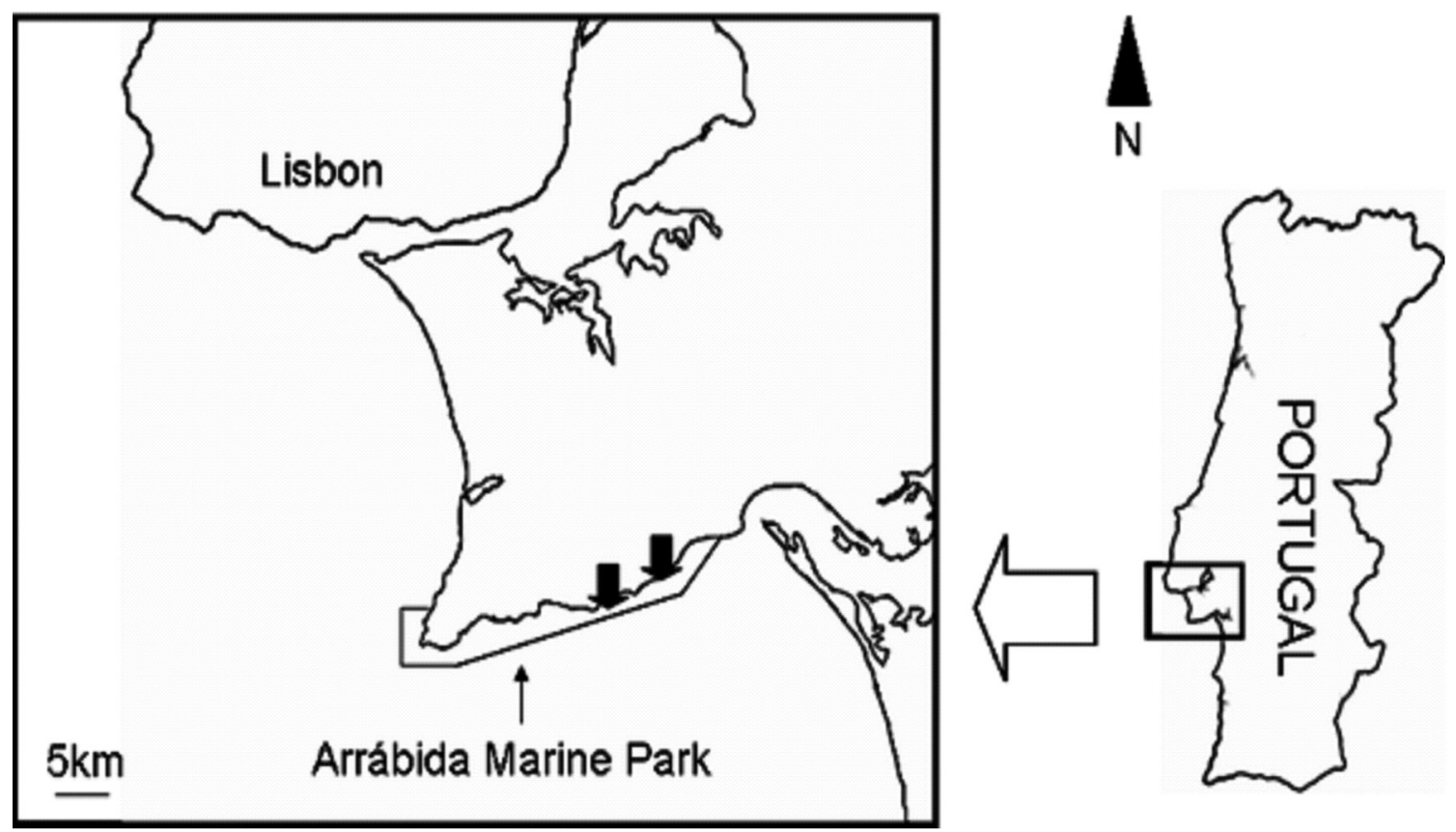

Figure 1. Arrábida Marine Park location on the Portuguese coast and sampling sites (black arrows).

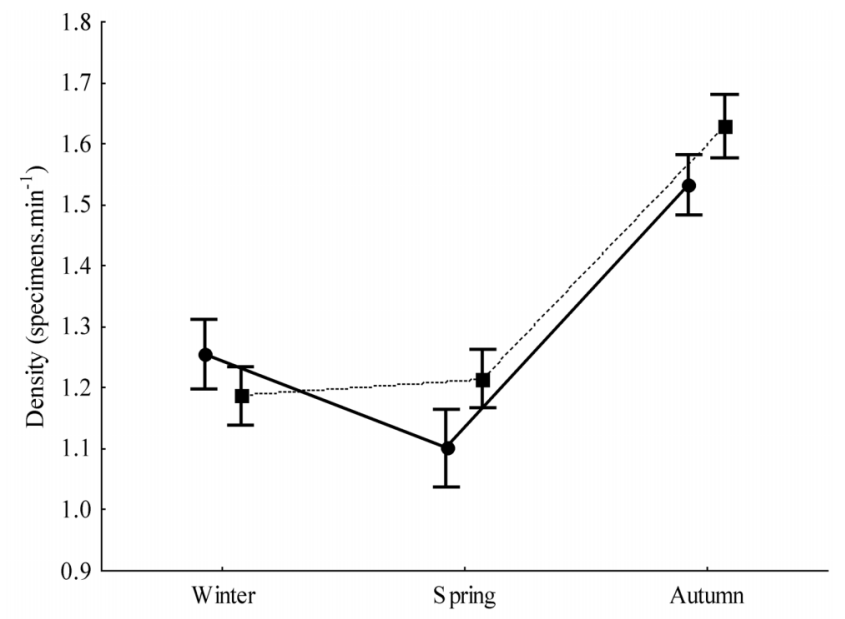

Figure 2. Density $\left(\right.$ specimens $\left.\times \min ^{-1}\right)$ values for the whole assemblage in the three sampling periods in 2002 (circles) and 2003 (squares). Vertical bars denote 0.95 confidence limits.

temporal diversity, density and structure variation of this assemblage.

\section{MATERIALS AND METHODS \\ Sampling location}

This study was carried out in the Arrábida Marine Park (Portugal), from January 2002 to December 2003. The Arrábida Marine Park was created in 1998 but management and protection measures were only approved in 2005. Two sites, presently part of a full protection area, were sampled (Figure 1) in the sector identified as having the highest biodiversity (Gonçalves et al., 2002). In this

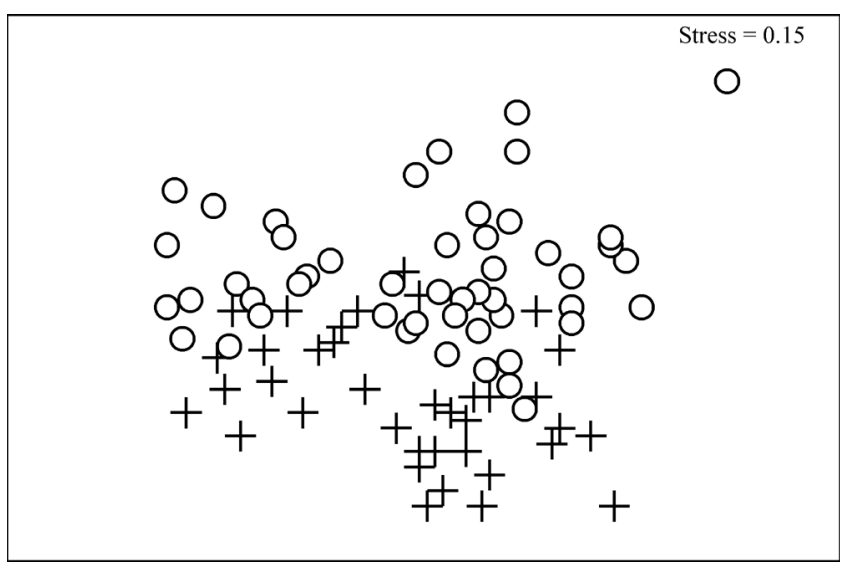

Figure 3. Multidimensional scaling ordination showing differences between the cryptobenthic fish assemblage in each year. Each individual point represents a replicate sample (census). Circles, 2003; crosses, 2002.

Marine Park, the underwater rocky habitats are highly heterogeneous and partially derive from the disintegration of the calcareous cliffs that border the coastline. The underwater rocky bottom extends offshore for several tens of metres and is composed of mixed patches of sand, gravel, cobbles, small rocks, large rocks and bedrock.

\section{Data collection}

To assess seasonal variation in diversity and abundance of the cryptobenthic fish assemblage, sampling activities were carried out in the winter (January-February), spring (April-May) and autumn (October-November). 
Table 2. Number of specimens of the rocky cryptobenthic assemblage recorded for each species in each season in 2002 and 2003 , at the Arrábida Marine Park.

\begin{tabular}{|c|c|c|c|c|c|c|c|c|}
\hline \multirow[b]{2}{*}{ Family } & \multirow[b]{2}{*}{ Species } & \multicolumn{3}{|c|}{2002} & \multicolumn{3}{|c|}{2003} & \multirow[b]{2}{*}{ Total } \\
\hline & & $\mathrm{W}$ & $\mathrm{S}$ & A & W & $\mathrm{S}$ & A & \\
\hline \multirow[t]{5}{*}{ Blenniidae } & Parablennius pilicornis & 535 & 419 & 464 & 307 & 278 & 338 & 2341 \\
\hline & Parablennius gattorugine & 18 & 16 & 66 & 28 & 29 & 27 & 184 \\
\hline & Lipophrys pholis & & & & & 1 & & 1 \\
\hline & Parablennius ruber & & & & & & 1 & 1 \\
\hline & Parablennius sanguinolentus & & & & & 1 & & 1 \\
\hline Callyonimidae & Callionymus reticulatus & 1 & 1 & 24 & 5 & 3 & 6 & 40 \\
\hline Congridae & Conger conger & & & & 1 & 1 & & 2 \\
\hline \multirow[t]{2}{*}{ Gadidae } & Gaidropsarus mediterraneus & 1 & 4 & 9 & 2 & 7 & 1 & 24 \\
\hline & Gaidropsarus vulgaris & & & & 1 & 1 & 3 & 5 \\
\hline \multirow{4}{*}{ Gobiesocidae } & Lepadogaster spp. & 34 & 35 & 88 & 109 & 147 & 119 & 532 \\
\hline & Lepadogaster candollii & 37 & 28 & 74 & 87 & 54 & 73 & 353 \\
\hline & Apletodon dentatus & & 3 & & & 4 & 4 & 11 \\
\hline & Diplecogaster bimaculata & & 3 & & & & 2 & 5 \\
\hline \multirow[t]{7}{*}{ Gobiidae } & Gobius xanthocephalus & 365 & 231 & 776 & 303 & 270 & 921 & 2866 \\
\hline & Gobius paganellus & 41 & 32 & 136 & 103 & 99 & 113 & 524 \\
\hline & Gobius cruentatus & 37 & 30 & 55 & 31 & 50 & 57 & 260 \\
\hline & Pomatoschistus pictus & 16 & 5 & 68 & 15 & 32 & 89 & 225 \\
\hline & Thorogobius ephippiatus & 2 & 1 & & & 2 & 4 & 9 \\
\hline & Chromogobius britoi & & & & & & 2 & 2 \\
\hline & Gobius cobitis & & 1 & & & & & 1 \\
\hline Muraenidae & Muraena helena & 3 & 3 & 4 & 4 & 3 & 5 & 22 \\
\hline \multirow[t]{2}{*}{ Scophthalmidae } & Phrynorhombus regius & 1 & & 2 & 1 & 2 & & 6 \\
\hline & Zeugopterus punctatus & & 1 & & & 1 & & 2 \\
\hline \multirow[t]{2}{*}{ Scorpaenidae } & Scorpaena notata & 21 & 3 & 10 & 3 & 4 & 3 & 44 \\
\hline & Scorpaena porcus & 5 & 4 & 6 & 6 & 4 & 3 & 28 \\
\hline \multirow[t]{3}{*}{ Syngnathidae } & Syngnathus acus & & & 3 & 10 & 3 & 8 & 24 \\
\hline & Nerophis lumbriciformis & & 1 & 1 & 9 & 7 & 4 & 22 \\
\hline & Entelurus aequoreus & & 1 & 4 & & 1 & & 6 \\
\hline Tripterygiidae & Tripterygion delaisi & 264 & 209 & 395 & 280 & 310 & 597 & 2055 \\
\hline
\end{tabular}

W, winter; S, spring; A, autumn.

Table 3. Two-way nested analysis of variance results for species richness, Shannon diversity index, evenness index and density between years and across seasons within years.

\begin{tabular}{|c|c|c|c|c|c|c|c|c|c|c|c|c|c|}
\hline & \multirow[b]{2}{*}{$\mathrm{df}$} & \multicolumn{3}{|c|}{ Species richness } & \multicolumn{3}{|c|}{ Shannon index } & \multicolumn{3}{|c|}{ Evenness } & \multicolumn{3}{|c|}{ Density } \\
\hline & & MS & $\mathrm{F}$ & $P$ & MS & $\mathrm{F}$ & $P$ & MS & $\mathrm{F}$ & $P$ & MS & $\mathrm{F}$ & $P$ \\
\hline Year & 1 & 0.199 & 0.093 & 0.093 & 0.071 & 21.08 & $<0.001$ & 0.483 & 26.00 & $<0.001$ & 0.008 & 46.24 & 0.055 \\
\hline Season (year) & 4 & 3.480 & 1.632 & 0.174 & 0.035 & 10.50 & $<0.001$ & 0.211 & 11.37 & $<0.001$ & 0.133 & 79.19 & $<0.001$ \\
\hline Error & 81 & 2.132 & & & 0.003 & & & 0.018 & & & 0.002 & & \\
\hline
\end{tabular}

A total of $91 \mathrm{~h}$ in 87 visual counts were performed (Table 1). In the summer months, sampling was not possible due to the occurrence of fast growing macroalgae (Cystoseira usneoides, Sacchorhiza polyshides and Laminaria digitata). These algae cover the substrate in very high densities making any visually-based census method impracticable. Censuses were performed in the morning between 1000 and $1230 \mathrm{~h}$, except on one occasion when the census was performed at $1700 \mathrm{~h}$. Strip transects were laid perpendicularly to the coastline, from the deeper rocky area (mean depth $=9.5 \mathrm{~m} ; \mathrm{SD}=1.6$ ) to the lower limit of the intertidal (mean depth $=2.5 \mathrm{~m} ; \mathrm{SD}=0.8$ ). Overall the average length of transects surveyed was $63.9 \mathrm{~m}(\mathrm{SD}=9.8$, range $=40-87.3 \mathrm{~m}$ ) and their width was $1 \mathrm{~m}$. Transects were laid in the same areas in the different seasons to assure that the same proportions of habitat types were sampled in the different seasons. Water temperature, measured at the beginning of each census, was significantly higher in $2002\left(\right.$ mean $\left.=16.42^{\circ} \mathrm{C}, \quad \mathrm{SD}=1.48^{\circ} \mathrm{C}\right)$ than in 2003 $\left(\right.$ mean $=15.08^{\circ} \mathrm{C}, \quad \mathrm{SD}=0.24^{\circ} \mathrm{C}$ ) (one-way analysis of variance (ANOVA): $\mathrm{F}=14.13, P<0.001)$.

Each cryptobenthic fish inside the transects was recorded, and its total length (TL) visually estimated. We followed Miller's (1979) definition of cryptobenthic fish but 

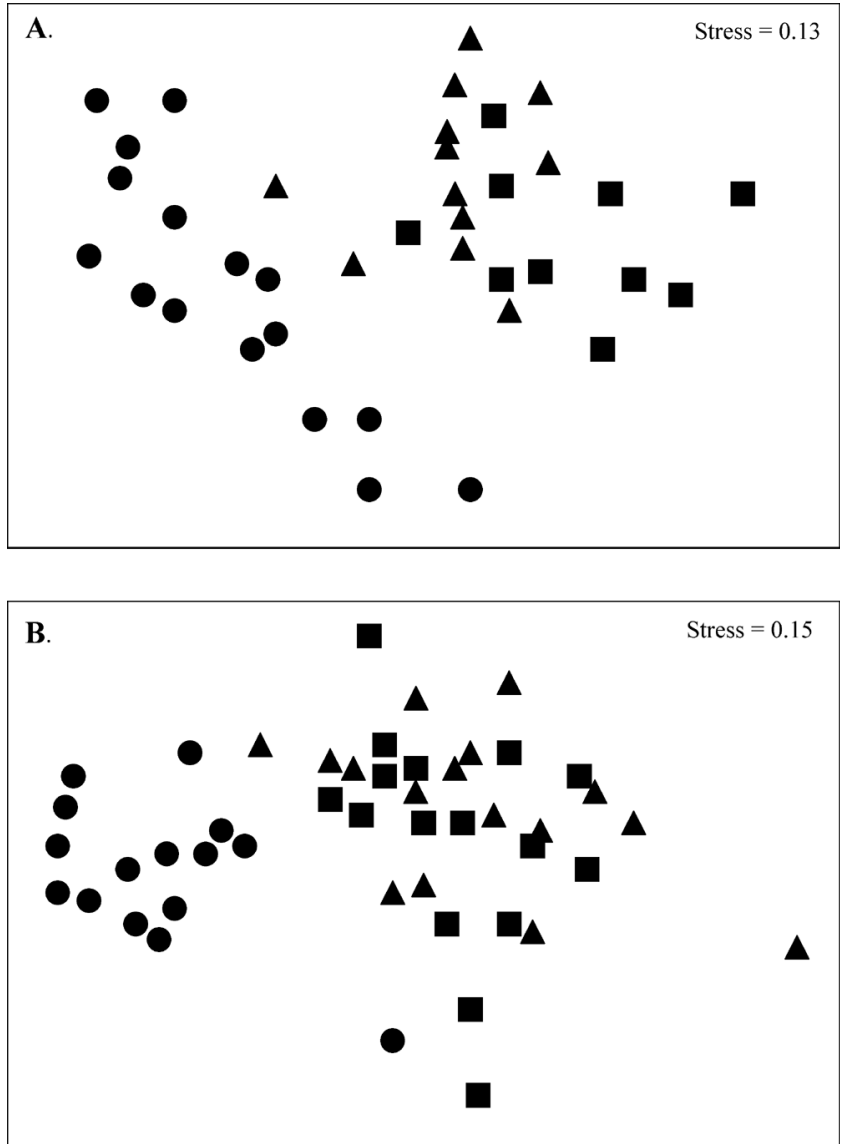

Figure 4. Multidimensional scaling ordinations showing seasonal differences in (A) 2002; and (B) 2003. Each individual point represents a replicate sample (census). Triangles, winter; squares, spring; circles, autumn.

Table 4. Post-hoc comparisons for the Shannon diversity index, evenness index and density across seasons within each year.

\begin{tabular}{llccc}
\hline Year & Season & Shannon & Evenness & Density \\
\hline 2002 & Winter-spring & n.s. & n.s. & $P<0.01$ \\
& Autumn-winter & n.s. & $P<0.001$ & $P<0.001$ \\
& Autumn-spring & n.s. & $P<0.05$ & $P<0.001$ \\
2003 & Winter-spring & n.s. & n.s. & n.s. \\
& Autumn-winter & $P<0.001$ & $P<0.001$ & $P<0.001$ \\
& Autumn-spring & $P<0.001$ & $P<0.001$ & $P<0.001$ \\
\hline
\end{tabular}

n.s., not significant.

included species larger than $10 \mathrm{~cm}$. All fish were easily identified according to distinct morphological and coloration characteristics except for Lepadogaster lepadogaster and L. purpurea. Due to the difficulty in distinguishing them in the field (Henriques et al., 2002) these species were recorded as Lepadogaster spp.

Considering the importance of training in visual size estimation of small specimens (Edgar et al., 2004), we performed visual estimation tests prior to every sampling season. Correlations between estimated and real values were always higher than 0.90 . The visual census technique used was an interference technique which involved disturbing certain microhabitats, like sand or gravel, and dismantling others, like small rocks or cobble, to look for fish in any accessible hideout that might be occupied (Beldade \& Gonçalves, in press). The visual counts performed are a modification of the timed counts used by Syms (1995). Each census was of variable duration given that length of transects and complexity of habitats was variable. Minimum sampling time per season was established on the basis of a cumulative number of species by time curve (with an asymptote at $90 \%$ of the number of species) in 2002. The time necessary to sample different microhabitat types varied, but density by time and by area were highly correlated in the 49 out of 87 censuses where both area and duration were recorded $r=0.934$, $P<0.001)$. All density values are expressed as number of fish $\times \min ^{-1}$.

\section{Data analysis \\ Assemblage composition and dynamics}

Fish assemblage heterogeneity was specified by calculating species richness, diversity (Shannon-Wiener index) and evenness (Zar, 1986). A two-way nested ANOVA was used to assess yearly and seasonal variations in the above mentioned assemblage parameters and in overall density $\left(\right.$ specimens $\left.\times \min ^{-1}\right)$. Post-hoc tests were used to find out where seasonal differences lay. Density data were transformed following a $\log (\mathrm{x}+1)$ function to meet parametric assumptions (Zar, 1986).

\section{Assemblage structure dynamics}

Multivariate analyses were used to assess yearly and seasonal differences in assemblage structure using the PRIMER software package (Clark \& Warwick, 2001). An overall matrix was built to assess yearly differences, and two other matrices, one for each year, were built to assess differences among seasons. The original density matrices of samples by species were transformed into a Bray-Curtis similarity matrix. Based on the relative abundance of each species, non-metric multidimensional scaling (nMDS) diagrams were used to graphically display the inter-relationships among samples. In each plot, samples that are closer together are more similar to each other. Stress values smaller than 0.15 were considered a good portrayal of data (Clark, 1993).

To test for differences between years and seasons, multivariate analysis of similarity (ANOSIM) was used to identify differences in assemblage groupings (Clark \& Warwick, 2001). Similarity percentages analysis (SIMPER) was used to identify the main taxa responsible for the yearly and seasonal groupings, assuming a cut-off at 90\%. Clarke \& Warwick (2001) classified species for which the ratio similarity/SD is large as good discriminators or 'typical' species, given that they consistently contribute to the similarity between groups. We use the term typical species to refer to cases where the similarity/SD value is higher than 1.86 (sensu Clarke \& Warwick, 2001).

\section{Temporal variation in fish density}

For each dominant species we used non-parametric statistical techniques to assess density differences between years (Mann-Whitney $U$-test) and seasons in each year 
A. Gobius xanthocephalus

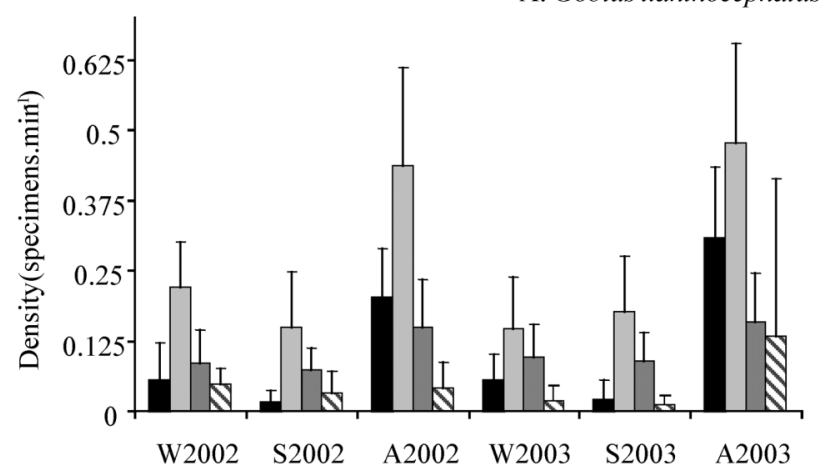

B. Tripterygion delaisi

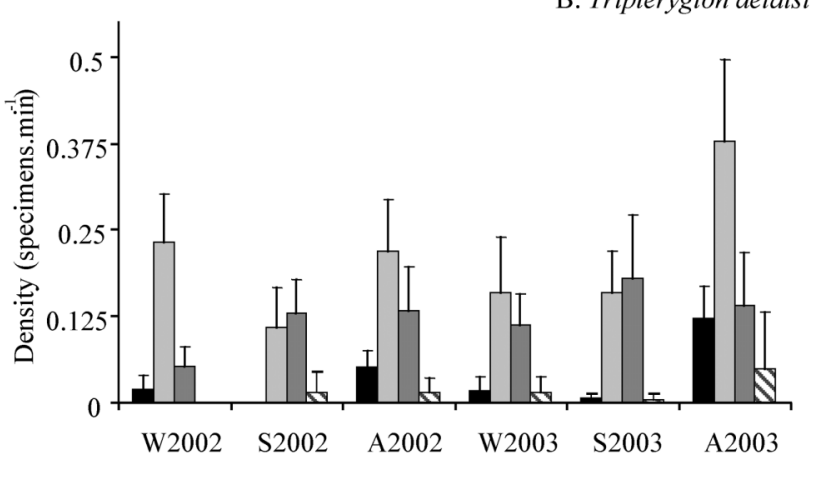

C. Parablennius pilicornis

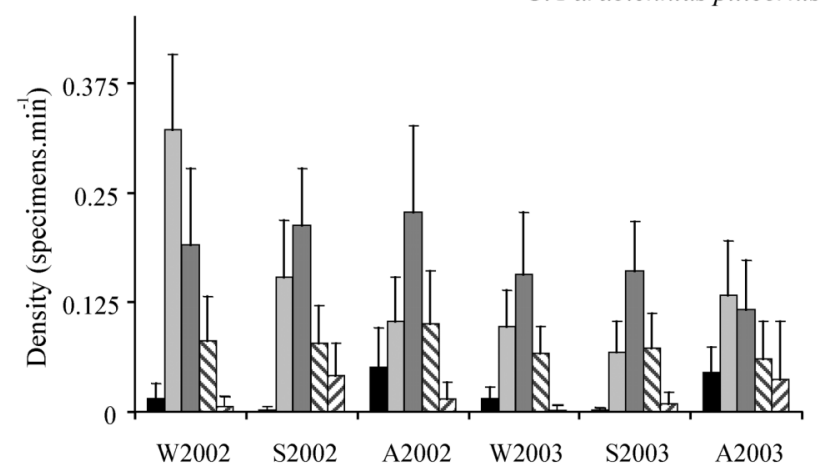

D. Gobius paganellus
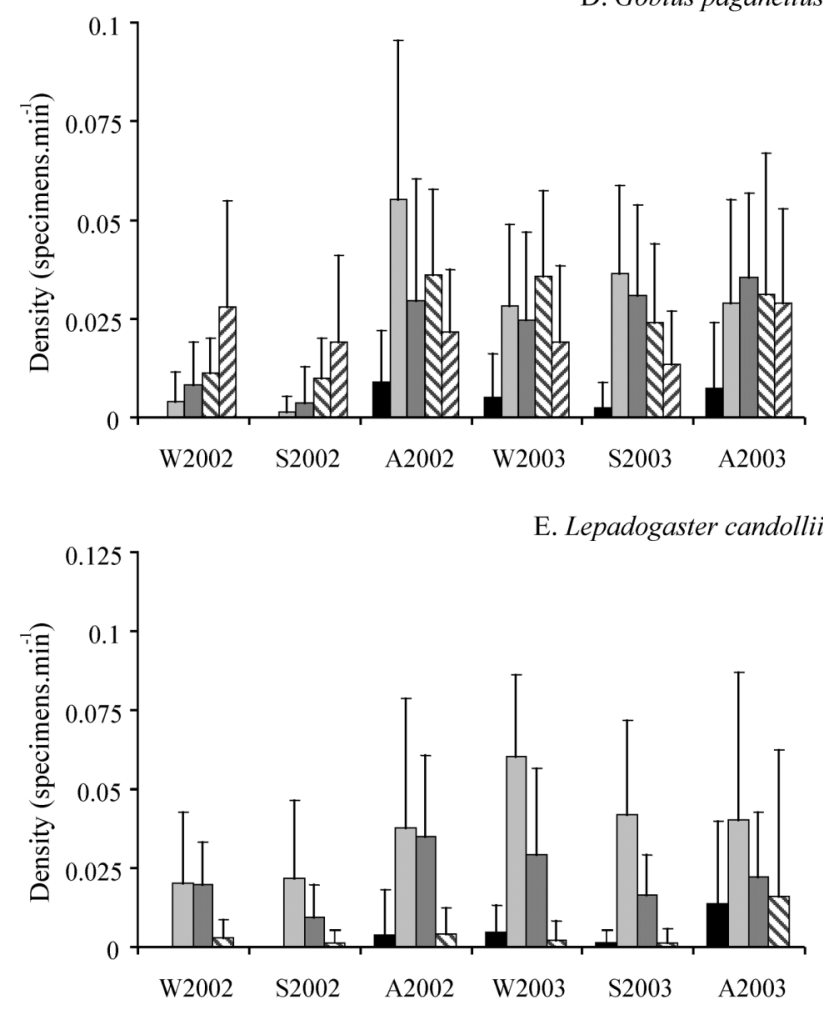

Figure 5. Two cm size-class density variation (mean $\pm \mathrm{SD})$ for $(\mathrm{A})$ Gobius xanthocephalus; (B) Tripterygion delaisi; (C) Parablennius pilicornis; (D) Gobius paganellus; and (E) Lepadogaster candollii in each season for both sampled years. Only individuals larger than $2 \mathrm{~cm}$ were included in the histogram. 2-3 cm, black bars; $4-5 \mathrm{~cm}$, light grey bars; $6-7 \mathrm{~cm}$, dark grey bars; and $8-9 \mathrm{~cm}, 10-12 \mathrm{~cm}$, crossed bars. Years, 2002 and 2003; Seasons: W, winter; S, spring; and A, autumn.

(Kruskal-Wallis ANOVA) given that parametric assumptions could not be met. Dunn's post-hoc tests were used to find out where differences lay (Zar, 1986). Density patterns for the different size-classes were also analysed for each season in each year.

\section{RESULTS}

\section{Assemblage composition and diversity}

A total of 9596 fish from 11 families and 30 species was recorded (Table 2). The assemblage was numerically dominated by seven species (Gobius xanthocephalus, Gobius paganellus, Parablennius pilicornis, Tripterygion delaisi, Lepadogaster spp. and Lepadogaster candollii), that comprised $90 \%$ of counts, with $73 \%$ of the species common to both years. Five species were only recorded in 2003 and one in
2002. An interesting result was the abundance rank change observed between years in $P$. pilicornis which fell from the most abundant in 2002 to the third place in 2003. This change was accompanied by an increase in the number of other species such as G. paganellus, Lepadogaster spp. and L. candollii.

Species richness and density did not differ between years, whereas the diversity indices were significantly higher in 2003, owing to changes in abundance of the main species (Tables 2 \& 3). In 2002, there were no differences in richness and Shannon index across seasons, but evenness was significantly higher in the autumn and density was significantly different across all seasons (Table 4; Figure 2). In 2003, species richness did not change across seasons but significant differences separated the autumn from the other seasons for the Shannon index, evenness and density (Table 4 and Figure 2). 
Table 5. Density variations between years and across seasons within each year for the most abundant species.

\begin{tabular}{|c|c|c|c|c|c|c|}
\hline & \multicolumn{2}{|c|}{ Yearly changes } & \multicolumn{2}{|c|}{ Seasonal changes (2002) } & \multicolumn{2}{|c|}{ Seasonal changes (2003) } \\
\hline & $\mathrm{Z}$ & $P$ & $\mathrm{H}$ & $P$ & $\mathrm{H}$ & $P$ \\
\hline Gobius xanthocephalus & 0.80 & 0.426 & 17.61 & $<0.001$ & 27.41 & $<0.001$ \\
\hline Tripterygion delaisi & 1.75 & 0.08 & 18.01 & $<0.001$ & 24.05 & $<0.001$ \\
\hline Parablennius pilicornis & 6.11 & $<0.001$ & 5.85 & 0.054 & 3.23 & 0.199 \\
\hline Gobius paganellus & 2.98 & $<0.001$ & 17.53 & $<0.001$ & 0.36 & 0.837 \\
\hline Lepadogaster candollii & 2.96 & $<0.001$ & 5.45 & 0.066 & 8.67 & $<0.05$ \\
\hline Lepadogaster spp. & 3.51 & $<0.001$ & & & & \\
\hline
\end{tabular}

Z, Mann-Whitney $U$-test; H, Kruskal-Wallis analysis of variance.

Table 6. Dunn's test results for the post-hoc comparisons of the seasonal density variation for the most abundant species.

\begin{tabular}{|c|c|c|c|c|c|c|}
\hline \multirow{2}{*}{$\begin{array}{l}\text { Year } \\
\text { Season comparison }\end{array}$} & \multicolumn{3}{|c|}{2002} & \multicolumn{3}{|c|}{2003} \\
\hline & $\mathrm{W}-\mathrm{S}$ & $\mathrm{A}-\mathrm{W}$ & $\mathrm{A}-\mathrm{S}$ & $\mathrm{W}-\mathrm{S}$ & $\mathrm{A}-\mathrm{W}$ & $\mathrm{A}-\mathrm{S}$ \\
\hline Gobius xanthocephalus & n.s. & $P<0.05$ & $P<0.001$ & n.s. & $P<0.001$ & $P<0.001$ \\
\hline Tripterygion delaisi & n.s. & $P<0.05$ & $P<0.001$ & n.s. & $P<0.001$ & $P<0.001$ \\
\hline Gobius paganellus & n.s. & $P<0.05$ & $P<0.001$ & n.s. & n.s. & n.s. \\
\hline Lepadogaster candollii & n.s. & n.s. & n.s. & $P<0.05$ & n.s. & n.s. \\
\hline
\end{tabular}

W, winter; S, spring, A, autumn; n.s., not significant.

\section{Assemblage structure dynamics}

Assemblage structure changed both between years and across seasons. The nMDS plot showed some degree of segregation among samples according to year (Figure 3) which was confirmed by the ANOSIM results (global R value of 0.36 and $P<0.001)$. There was a clear separation of samples by season in each year mainly due to the autumn samples (Figure 4A,B). Both in 2002 and 2003, significant differences among seasons in the assemblage composition were detected (2002: $\mathrm{R}=0.53, \quad P<0.001$; 2003: $\mathrm{R}=0.55, P<0.001$ ). Pairwise comparisons showed that the autumn was significantly different from the other seasons in both years.

The SIMPER results showed that in the yearly comparison, P. pilicornis, G. xanthocephalus, T. delaisi and G. paganellus were considered as typical species (see Materials and Methods). In the seasonal analysis, typical species were: P. pilicornis and G. xanthocephalus in all seasons; T. delaisi in every season except spring 2002; G. paganellus in winter 2002 and in all seasons in 2003; L. candollii in winter 2003; and Lepadogaster spp. in spring 2003.

\section{Temporal variation in fish density}

Density variations of the typical species showed three different temporal patterns between years: (i) a significant density increase; (ii) decrease; or (iii) no significant density change. These species can additionally be grouped into three different categories of seasonal patterns: (1) a clear density increase in the autumn in both years; (2) a density increase in the autumn only in one year; or (3) other seasonal pattern.
Densities did not change significantly between years for G. xanthocephalus and T. delaisi, but there were significant seasonal changes for these species (Table 5). In the autumn, significantly higher densities were recorded in both years (Table 6). The density of small individuals of $G$. xanthocephalus clearly increased in the autumn of the two years, whereas small T. delaisi only increased in the autumn of 2002 (Figure 5A,B).

Parablennius pilicornis presented significant annual density variations, with lower values in 2003, but no seasonal variations (Table 5). Small specimens were more abundant in the winter in 2002 and in the autumn in 2003 (Figure 5G).

Although there was a density increase in 2003 for G. paganellus and L. candollii (Table 5), their seasonal patterns differed. There were significant seasonal changes in 2002 for G. paganellus but not for L. candollii. In 2003 this pattern reversed (Tables $5 \& 6$ ). The increase in density for G. paganellus in the autumn of 2002 coincided with an increase in the number of small individuals (Figure 5D,E). For L. candollii, there was a decrease in 2003 from the winter to the spring (Table 6).

\section{DISCUSSION}

As in other studies on temperate cryptobenthic fish (Willis, 2001; La Mesa et al., 2004), relatively few taxa were numerically dominant in our assemblage. The abundance of clingfish (Lepadogaster spp. and L. candollii) was noteworthy especially in comparison with data collected elsewhere (Falcón et al., 1993; Reñones et al., 1997; La Mesa \& Vacchi, 1999; Magill \& Sayer, 2002; La Mesa et 
al., 2004). This outcome was probably derived from the sampling technique used here. More reliable results on the abundance of clingfish, which occur preferably under cobbles and rocks (Hofrichter \& Patzner, 2000; Henriques et al., 2002) and can be missed by traditional visual sampling techniques (Willis, 2001), were likely ensured by habitat dismantling. Furthermore our sampling technique has a very transient impact on the environment and is therefore highly suited for temporal dynamics studies.

Species richness did not change significantly between years. However, significantly higher diversity indices were recorded in the second year due to the higher number of individuals of abundant species, such as Lepadogaster spp., L. candollii and Gobius paganellus. Even though overall density was similar between years, there were significant increases (G. paganellus, L. candollii and Lepadogaster spp.) and decreases (Parablennius pilicornis) among the most abundant species. Multivariate analyses did not show strong differences between years and the same typical species (sensu Clark \& Warwick, 2001) were identified in each year (except for $G$. paganellus) in spite of the density variations between years.

The constant overall density values observed are in accordance with what has been described for the highly resilient and stable intertidal fish communities (Almada \& Faria, 2004). However, other studies on coastal subtidal fish assemblages (encompassing both pelagic and cryptobenthic species) have found strong seasonal density fluctuations (Magill \& Sayer, 2002). These density variations are probably more related to changes in pelagic species, which have strong inter-annual density fluctuations (Fogarty et al., 1991), than to variations in cryptobenthic fish assemblages. However, more studies are needed to determine the relative contribution of cryptobenthic species to the overall variation observed in fish coastal assemblages. Only two years of data have been analysed in the present work and results need therefore to be interpreted with caution.

Species richness did not change seasonally within each year. However, in 2002, the higher number of abundant species in the autumn originated higher diversity indices. These results contrast with the patterns described by La Mesa \& Vacchi (1999) who found no seasonal effect on the same diversity indices for a coastal fish community in Ustica Island Marine Reserve. In the present study, over two years, the density of the whole assemblage showed the same seasonal pattern in which density peaked in the autumn and was the lowest in the spring. Similar seasonal trends have been described for several other fish species in temperate regions (Wilkins \& Myers, 1992). Strong seasonal patterns are also commonly found in intertidal fish (Almada \& Faria, 2004).

We could not sample the assemblage during the summer months. However, many of the cryptobenthic species spawn during the spring and summer and probably start to settle at the end of summer. Given that changes in density can be very sharp and concentrated in time, for example, Connell \& Jones (1991) recorded a decrease of $60 \%$ within the first month of recruitment, fluctuations may be greater than the ones described here. Multivariate analyses clearly separated the autumn from the other seasons in each year. For $G$. xanthocephalus, Tripterygion delaisi and $G$. paganellus, the increases in density in the autumn coincided with an increase in the density of small individuals. Therefore, these fluctuations seem to be related to recruitment in these species. The smaller G. paganellus were absent from our counts, which could be explained by their known recruitment to the intertidal (Faria \& Almada, 1999).

The linkage between seasonal fluctuations in density and higher number of recruits, suggests that strong postsettlement processes are shaping the cryptobenthic assemblage. It is possible to speculate that population densities may be limited and regulated by post-settlement processes rather than by the input of settlers (Steele, 1997; Macphersen \& Zika, 1999). For instance, Depczynski \& Bellwood (2005) have recently found high mortality rates for a cryptobenthic coral reef fish (the pygmy goby Eviota sigillata), a species with the shortest recorded lifespan among vertebrates. Besides the role as trophic links between lower and higher order predators that cryptobenthic fish have, the high fluctuations in density across seasons observed for most species, implies a high-energy turnover that will certainly have a significant impact on the local coastal community (Depczynski \& Bellwood, 2003).

The implications of these results are relevant not only for understanding the dynamics of an often overlooked component of temperate reef fish populations, but also for biodiversity management of the Marine Park. Understanding the structure, composition and temporal variation of these assemblages and decoupling this natural variation from that derived from the protection measures applied, is a central aspect for management. This study preceded the approval of the Arrábida Marine Park legislation and may therefore be used in the future for comparative purposes.

This study was supported by the Portuguese Science and Technology Foundation (Fundação para a Ciência e a Tecnologia-FCT) as part of the project POCTI/BSE/38350/ 2001 and through the Pluriannual Programme (R\&D Unit 331/ 94). The FCT also supported the PhD grant of R. Beldade (SFRH/BD/1013/2000). We thank two anonymous referees for their comments on the manuscript. Special thanks to N. Sousa for invaluable field assistance and to the Arrábida Nature Park for logistic support.

\section{REFERENCES}

Almada, V.C. \& Faria, C., 2004. Temporal variation of rocky intertidal resident fish assemblages - patterns and possible mechanisms with a note on sampling protocols. Reviews in Biology and Fisheries, 14, 239-250.

Anderson, M.J. \& Millar, R.B., 2004. Spatial variation and effects of habitat on temperate reef fish assemblages in northeastern New Zealand. Journal of Experimental Marine Biology and Ecology, 305, 191-221.

Beldade, R. \& Gonçalves, E.J., in press. An interference visual census technique applied to cryptobenthic fish assemblage. Vie et Millieu.

Blackburn, T.M. \& Gaston, K.J., 1996. Abundance-body size relationships: the area you census tells you more. Oikos, 75, 303-309.

Clark, K.R., 1993. Non-parametric multivariate analyses of changes in community structure. Australian fournal of Ecology, 18, 117-143. 
Clark, K.R. \& Warwick, R.M., 2001. Change in marine communities: an approach to statistical analysis and interpretation, 2nd edn. Plymouth: PRIMER-E.

Connell, S.D. \& Jones, G.P., 1991. The influence of habitat complexity on postrecruitment processes in a temperate reef fish population. Fournal of Experimental Marine Biology and Ecology, 151, 271-294.

Costello, M.J., 1992. Abundance and spatial overlap of gobies (Gobiidae) in Lough Hyne, Ireland. Environmental Biology of Fishes, 33, 239-248.

Cushing, D., 1995. Population production and regulation in the sea-a fisheries perspective. Cambridge: Cambridge University Press.

Depczynski, M. \& Bellwood, D.R., 2003. The role of cryptobenthic reef fish in coral reef trophodynamics. Marine Ecology Progress Series, 256, 183-191.

Depczynski, M. \& Bellwood, D.R., 2005. The shortest vertebrate lifespan found in a coral reef. Current Biology, 15, 288-289.

Doherty, P.J. \& Williams, D.M., 1988. The replenishment of coral reef fish populations. Oceanography and Marine Biology. Annual Reviere, 26, 487-551.

Edgar, G.J., Barrett, N.S. \& Moroton, A.J., 2004. Bias associated with the use of underwater visual census techniques to quantify the density and size-structure of fish populations. Fournal of Experimental Marine Biology and Ecology, 308, 269-290.

Falcón, J.M., Mena, J., Brito, A., Rodriguez, F.M. \& Mata, M., 1993. Ictiofauna de los fondos infralitorales rocosos de las islas Canarias. Observaciones mediante muestreos visuales in situ. Publicaciones Especiales del Instituto Español de Oceanografia, 11, 205-215.

Faria, C. \& Almada, V.G., 1999. Variation and resilience of rocky intertidal fish in Western Portugal. Marine Ecology Progress Series, 184, 197-203.

Fogarty, M.J., Sissenwine, M.P. \& Cohen, E.B., 1991. Recruitment variability and the dynamics of exploited marine populations. Trends in Ecology and Evolution, 6, 241-246.

Forrester, G.E., 1995. Strong density-dependent survival and recruitment regulate the abundance of a coral reef fish. Oecologia, 103, 275-282.

García-Charton, J.A., Peréz-Ruzafa, Á., Sanchez-Jérez, P., Bayle-Sempere, J.T., Reñones, O. \& Moreno, D., 2004. Multi-scale spatial heterogeneity, habitat structure, and the effect of marine reserves on western Mediterranean rocky reef assemblages. Marine Biology, 144, 161-182.

Gonçalves, E.J., Henriques, M. \& Almada, V.C., 2002. Use of a temperate reef-fish community to identify priorities in the establishment of a Marine Protected Area. In Proceedings of the World Congress on Aquatic Protected Areas, Cairns, Australia, 14-17 August 2002. Aquatic Protected Areas: What Works Best and How Do We Know? (ed. J.P. Beumer et al.) pp. 261-272. Australian Society for Fisheries Biology.

Harmelin-Vivien, M.L. et al., 1985. Évaluation visuelle des peuplements et populations de poissons: méthodes et problèms. Revue d'Ecologie (Terre Vie), 40, 467-539.

Henriques, M., Lourenço, R., Almada, F., Calado, G., Gonçalves, D., Guillemaud, T., Cancela, M.L. \& Almada, V.C., 2002. A revision of the status of Lepadogaster lepadogaster (Pisces: Gobiesocidae) sympatric sub-species or a long misunderstood blend species? Biological Fournal of the Linnean Society, 76, 327-338.

Hofrichter, R. \& Patzner, R.A., 2000. Habitat and microhabitat of Mediterranean clingfish (Teleostei: Gobiesociformes: Gobiesocidae). Marine Ecology, 21, 41-53.
Illich, I.P. \& Kotrschal, K., 1990. Depth distribution and abundance of northern Adriatic littoral rocky reef blennioid fish (Blenniidae and Tripterygion). Marine Ecology, 11, 277-289.

Jansson, B.-O., Aneer, G. \& Nellbring, S., 1985. Spatial and temporal distribution of the demersal fish fauna in a Baltic archipelago as estimated by scuba census. Marine Ecology Progress Series, 23, 31-43.

La Mesa, G., Micalizzi, M., Giaccone, G. \& Vacchi, M., 2004. Cryptobenthic fish of the "Ciclopi Islands" marine reserve (central Mediterranean Sea): assemblage composition, structure and relations with habitat features. Marine Biology, 145, 233-242.

La Mesa, G. \& Vacchi, M., 1999. An analysis of the coastal fish assemblage of the Ustica Island Marine Reserve (Mediterranean Sea). Marine Ecology, 20, 147-165.

Macpherson, E., 1994. Substrate utilization in a Mediterranean littoral fish community. Marine Ecology Progress Series, 114, 211-218.

Macpherson, E. \& Zika, U., 1999. Temporal and spatial variability of settlement success and recruitment level in three blennoid fish in the north-western Mediterranean. Marine Ecology Progress Series, 182, 269-282.

Magill, S.H. \& Sayer, M.D.J., 2002. Seasonal and interannual variation in fish assemblages of northern temperate rocky subtidal habitats. Fournal of Fish Biology, 61, 1198-1216.

Miller, P.J., 1979. Adaptiveness and implications of small size in teleosts. Symposium of the Zoological Society of London, 44, 263-306.

Minchin, D., 1987. Fish of the Lough Hyne Marine Reserve. Fournal of Fish Biology, 31, 343-352.

Miniconi, R., Francour, P. \& Bianconi, C.-H., 1990. Inventaire de la faune ichthyologique de la réserve naturelle de Scandola (Corse, Méditerranée nord-occidentale). Cybium, 14, 77-89.

Ordines, F., Moranta, J., Palmer, M.A., Lerycke, A., Suau, A., Morales-Nin, B. \& Grau, A.M., 2005. Variations in a shallow rocky reef fish community at different spatial scales in the western Mediterranean Sea. Marine Ecology Progress Series, 304, 221-233.

Reñones, O., Moranta, J., Coll, J. \& Morales-Nin., B., 1997. Rocky bottom fish communities of Cabrera Archipelago National Park (Mallorca, western Mediterranean). Scientia Marina, 61, 495-506.

Steele, M., 1997. Population regulation by post-settlement mortality in two temperate reef fish. Oecologia, 112, 64-74.

Stephens, J.S.J., Morris, P.A., Zerba, K. \& Love, M., 1984. Factors affecting fish diversity on a temperate reef: the fish assemblage of Palos Verdes Point, 1974-1981. Environmental Biology of Fishes, 11, 259-275.

Syms, C., 1995. Multi-scale analyses of habitat association in a guild of blennioid fish. Marine Ecology Progress Series, 125, 31-43.

Wilkins, H.K.A. \& Myers, A.A., 1992. Microhabitat utilisation by an assemblage of temperate Gobiidae (Pisces: Teleostei). Marine Ecology Progress Series, 90, 103-112.

Willis, T.J., 2001. Visual census methods underestimate density and diversity of cryptic reef fish. Fournal of Fish Biology, 59, 1408-1411.

Zar, J.H., 1986. Biostatistical analysis, 3rd edn. Prentice Hall: New Jersey. 